\title{
Peter Wallensteen
}

\section{Om konfliktmönster i dagens värld}

\begin{abstract}
Krig och andra väpnade konflikter skiljer sig på flera betydelsefulla sätt från vardagskonflikterna. En viktigt skillnad är statens speciella karaktär, som diskuteras närmare. Samtidigt konstateras att statens tolkningsmonopol på rätten att använda vapenmakt har ifrågasatts frånn olika hâll. En genomgång av data om krigsmönster ger dels ett perspektiv på 1900-talet som ett av de mest brutala, dels skäl att fråga om vilka följder det andra världskriget medförde. Det är till exempel tveksamt om kärnvapnen verkligen minskat mängden konflikter jämfört med tidigare perioder. Konflikterna av idag analyseras som tre grundtyper, som ibland kan flätas in i varandre i konfliktkomplex. Möjligheten av lösning av dessa grundkonflikter diskuteras.
\end{abstract}

\begin{abstract}
Konflikt: vad är det?
"Konflikt" är ett vanligt begrepp. Några av ordets släktingar, såsom kamp, strid, krig ger stora rubriker och påminner om vapen, våld och död. Andra släktingar, såsom spänning och fientlighet leder tankarna till mänskliga attityder och uppfattningar. Besläktade ord är också motsättning, oförenlighet, intressekollision och orättvisa. Det är inte så märkligt att "konflikt" är ett vanligt förekommande ord. Det innehåller laddade associationer, som ofta är obehagliga och negativa. De uttrycker vanligen icke önskvärda avbrott i vardagen. Ibland kan dock "konflikt" vara synonymt med "problem". Det är en mer alldaglig association. Konflikter och problem förkommer ständigt på arbetsplatser, i hem eller i personliga relationer. Konflikter är vanliga företeelser och det övervägande flertalet hanteras utan att det ger upphov till rubriker eller utan att vi ens funderar närmare på dem.

Här avser vi med "konflikt" sådant fientligt beteende som utförs av en eller flera aktörer för att uppnå något som är högt värderat men som det samtidigt inte finns tillräckligt av för samtliga inblandade. Sådana konflikter kan förekomma på många nivåer i samhället.

Vissa konflikter leder till mänskligt lidande, materiell förstörelse, mentala förskjutningar och samhällsförändringar. Dessa konflikter skiljer sig från de alldagliga i flera, mycket viktiga avseenden. Tillsammans medför dessa skillnander att det är svårt att dra enkla paralleller mellan rubrikernas krig och vardagens konflikter. Några av de viktigaste skillnaderna har att göra med att dess konflikter drivs av organisationer snarare än individer. Detta ger en särskild karaktär åt konfliktens parter och därmed deras resurser. Det skapar också en särskilt dynamik mellan organisationens ledning och dess medlemmar. Denna kan ha stor betydelse för olika beslut. Varje organisation slår vakt om sin självständighet, dvs. rätten att själv ställa upp målen för verksamheten och försöka uppfylla dem. Även individer är i så måtto självständiga varför vi talar om en skillnad i nivå. En organisations självständighed innefattar inte nödvändigvis medlemmarnas individuella självständighet. Ofta tycks organisationer bli mål i sig själva och organisationens överlevnad kan bli viktigare än enstaka individers överlev-
\end{abstract}




\title{
Peter Wallensteen
}

\section{Om konfliktmönster i dagens värld}

\begin{abstract}
Krig och andra väpnade konflikter skiljer sig på flera betydelsefulla sätt från vardagskonflikterna. En viktigt skillnad är statens speciella karaktär, som diskuteras närmare. Samtidigt konstateras att statens tolkningsmonopol på rätten att använda vapenmakt har ifrågasatts frånn olika hâll. En genomgång av data om krigsmönster ger dels ett perspektiv på 1900-talet som ett av de mest brutala, dels skäl att fråga om vilka följder det andra världskriget medförde. Det är till exempel tveksamt om kärnvapnen verkligen minskat mängden konflikter jämfört med tidigare perioder. Konflikterna av idag analyseras som tre grundtyper, som ibland kan flätas in i varandre i konfliktkomplex. Möjligheten av lösning av dessa grundkonflikter diskuteras.
\end{abstract}

\begin{abstract}
Konflikt: vad är det?
"Konflikt" är ett vanligt begrepp. Några av ordets släktingar, såsom kamp, strid, krig ger stora rubriker och påminner om vapen, våld och död. Andra släktingar, såsom spänning och fientlighet leder tankarna till mänskliga attityder och uppfattningar. Besläktade ord är också motsättning, oförenlighet, intressekollision och orättvisa. Det är inte så märkligt att "konflikt" är ett vanligt förekommande ord. Det innehåller laddade associationer, som ofta är obehagliga och negativa. De uttrycker vanligen icke önskvärda avbrott i vardagen. Ibland kan dock "konflikt" vara synonymt med "problem". Det är en mer alldaglig association. Konflikter och problem förkommer ständigt på arbetsplatser, i hem eller i personliga relationer. Konflikter är vanliga företeelser och det övervägande flertalet hanteras utan att det ger upphov till rubriker eller utan att vi ens funderar närmare på dem.

Här avser vi med "konflikt" sådant fientligt beteende som utförs av en eller flera aktörer för att uppnå något som är högt värderat men som det samtidigt inte finns tillräckligt av för samtliga inblandade. Sådana konflikter kan förekomma på många nivåer i samhället.

Vissa konflikter leder till mänskligt lidande, materiell förstörelse, mentala förskjutningar och samhällsförändringar. Dessa konflikter skiljer sig från de alldagliga i flera, mycket viktiga avseenden. Tillsammans medför dessa skillnander att det är svårt att dra enkla paralleller mellan rubrikernas krig och vardagens konflikter. Några av de viktigaste skillnaderna har att göra med att dess konflikter drivs av organisationer snarare än individer. Detta ger en särskild karaktär åt konfliktens parter och därmed deras resurser. Det skapar också en särskilt dynamik mellan organisationens ledning och dess medlemmar. Denna kan ha stor betydelse för olika beslut. Varje organisation slår vakt om sin självständighet, dvs. rätten att själv ställa upp målen för verksamheten och försöka uppfylla dem. Även individer är i så måtto självständiga varför vi talar om en skillnad i nivå. En organisations självständighed innefattar inte nödvändigvis medlemmarnas individuella självständighet. Ofta tycks organisationer bli mål i sig själva och organisationens överlevnad kan bli viktigare än enstaka individers överlev-
\end{abstract}


nad. Så beskrivs ofta nödvändigheten av att underordna sig eller till och med offra livet för en organisations självständighet.

Men det är inte alla typer av organisationer som hamnar i väpnad konflikt med varandra. Företag och fackföreningar är starka och självständiga, liksom partier och organisationer. De är emellertid inte krigförande organisationer, och de utkämpar, normalt, inte sina konflikter med krig. I stället är det organisationer för vilka vapen spelar en särskild roll som är viktiga att skärskåda. Det finns ett antal sådana, bland vilka staten är den viktigaste. Låt oss därför se närmare på vad som skiljer staten från andra organisationer. Därefter ska vi också undersöka andra organisationer som har betydelse som krigförande aktör.

Staten (regeringsmakten) skiljer sig från andra självständiga aktörer bland annat på följande viss:

- Den har (ensamt) tilgång till tvångsmakt;

- den har (ensamt) rätt att använda tvångsmakt;

- den har (ensamt) rätt att beskatta invånarna och deras verksamhet;

- den har (ensamt) kontroll över ett viss territorium.

Statens anspråk på ensamrätt i vissa avseenden ger den givetvis en unik ställning. Denna rätt är emellertid inte oomtvistad. Tvärtom ligger fröet till mycken politisk dispyt just på denna punkt, vilket vi ska återkomma till.

Statens självständighet, vapenmakt, tolkningsmakt, skattemakt och territoriella kontroll gör den till en unik organiation. I jämförelse med andra organisationer är den oftast rikt finansierad, förfogar över en stor administrativ apparat och en tränad militärmakt. Den som kontrollerar regeringsmakten har till sitt förfogande en våldsarsenal av en sådan omfattning att vardagslivets förråd av köksknivar snabbt framstår som mycket begränsat. ${ }^{1}$

Statens speciella karaktär skiljer den också från andra välorganiserade aktörer såsom företag, fackförbund, partier, religiösa samfund. Den territoriella kontrollen är viktig för att förstå skillnaden mellan de stora, våldsamma konflikterna och det stora flertalet av mänskliga konflikter. Vapen är vanligen konstruerade för att hålla kontroll över landområden. Armén är ett exempel. Officerare och soldater tränas ständigt i vilka geografiska punkter som ska hållas på vilket sätt för att uppnå maximal territoriell kontroll. På samma sätt är flottan konstruerad för att utveckla och hålla kontroll över vattenområden. Återigen spelar särskilda stödjepunkter stor roll. Trånga passager, kanaler, öar, etc. är flottans motsvarighet till arméns pass, landsvägar och städer. Flygvapnet är, på ett litet annorlunda sätt, också skapad för kontroll, över luftrummet ovanför ett visst markområde. Flygets tillkomst förändrar dock den klassiska bilden. Det är svårare att försvara ett luftrum och därför öppnas vägen för attacker genom luften.

De militära vapner är alltså till för territoriell kontroll. Denna kontroll upprätthålls ytterst genom hotet om att skada och döda. Vapnen skiljer sig därmed från de medel som används till exempel i en arbetsmarknadskonflikt. Där eftersträvas i stället ekonomisk förlust. Dessa stridmedel är mindre skadliga (avsikten är att ingen ska dödas och det hotas normalt inge med död) och mindre territoriella. Syftet är inte att nå 
kontroll över en speciell fabrik eller anläggning utan att få fördelar/eftergifter av motparten i mer allmänna avseenden.

Staterna är inte alla lika starka. Somliga har mer resurser än andra. I ett internatioellt perspektiv kan också en rad icke-statliga organisationer (främst företag) vara starkare än vissa stater. Statens självständighet är därmed inte given. Olika typer av beroenden förändrar den teoretiska bilden av en värld fylld av självständiga och likvärdiga enheter högst avsevärt. Banden mellan staterna är av en sådan karaktär att en viss struktur uppstår, där stormakter dominerar vissa regioner och där självständigheten $\mathrm{i}$ praktiken är mycket begränsad. Sovjetunionens inflytande över östeuropa upprätthålls med hjälp av sovjetiska styrkor, kommunistpartiernas ställning och underrättelseorganisationernas, KGB och GRU, arbete. USAs inflytande i Centralamerika och Karibien, liksom Frankrikes inflytande över delar av Afrika är ytterligare exempel på hur sådana regionala strukturer kan se ut. Tvärs över statsgränserna går med andra ord band som skapar koalitioner och beroenden av olika slag.

I många länder finns, vid sidan om staten, en rad andra välorganiserade aktörer som också - lagligen eller inte - har tillgång till stor vapenmakt. Områden där centralregeringens kontroll är begränsad kan i praktiken styras av lokala hövdingar. Ett exempel är afarer i Etiopien. I många afrikanska samhällen finns motsättningar mellan nomader och den jordbrukande befolkningen, där regeringens inflytande över nomadena kan vara obetydligt. Ekonomiska intressenter kan ha skaffa sig stort lokalt inflytande vilket centralregeringen tvingas acceptera. Exempel är opiumodlare i det inre av Thailand och haschproducenter i Pakistan. I Libanon har centralregeringen förvandlats till en lokalt begränsad makt som måste förhandla med andra ledare som med vapen kontrollerar delar av landet.

I andra fall har centralregeringens kontroll reducerats till följd av framgångar för beväpnade frihetsrörelser som egentligen eftersträvar att ta över hela centralmakten. Exempel är upprättande av befriade territorier i Mocambique och Angola. Under 1960-talet gjordes detta av vänsteroppositionen i strid med kolonialmakten, under 1980-talet har samma skett men nu av högeropposition med hjälp av Sydafrika. I dessa fall har icke-statliga aktörer kommit att i praktiken utöva den regulära statsapparatens funktioner inom vissa territorier.

I ytterligare andra fall har grupper möjlighet använda vapen som medel utan att stadigvarande kontrollera något territorium alls. I USA är det tillåtet att privat äga stora vapenarsenaler och där finns gangstersyndikat som inte drar sig för vapenanvändning. Andra exempel är så kallate terrorister, som gör aktioner och sedan försvinner. Givetvis förutsätter detta ändå vissa basmöjligheter: platser att träna på och där vapen kan förvaras och planer smidas. Sådana tycks dock kunna upprättas, åtminstone $\mathrm{i}$ öppna samhällen, utan centralregeringens insyn. Världen är full av grupperingar som lyckas organisera, finansiera och använda vapen för att söka förverkliga politiska och/eller ekonomiska intressen. De är därmed parter i väpnade konflikter.

Ett särskilt problem ligger i statens "tillgång" till tvångsmakten: är det verkligen så att regeringen kontrollerar den tvångsmakten den är överordnad? Försvarsgrenarna brukar värna om sin självständighet, vilket ofta leder till rivalitet mellan dem, eller till och met väpnade konflikter. Krigsmaktens representanter kan också agera annorlunda än vad regeringen tänkt sig. Detta är ett problem i krissituationer, då militära beslutsfattare kan föredra vissa åtgärder som inte önskas av en civil regering. Regerin- 
gens kontroll kan visa sig vara formell snarare än reell. Ett annat stort problem är givetvis relationen mellan civil och militär makt $\mathrm{i}$ allmänhet. I många länder saknas en organiserade civil makt som kan stå emot den militära. Resultatet blir lätt militärkupper och långa perioder av militärt styre.

I samtliga dessa fall talar vi om organisationer som har en helt annant komplexitet än parterna i en vardagskonflikt. I vardagskonflikten är vapenanvändningen i princip förbjuden i det flesta samhällen. De enda undantagen är förknippade med så kallet nödvärnsrätt. Därmed skapas ett vapenmaktsmonopol i samhället: det är endast staten (och dess underorgan) som har rätt att använda văld för att uppnä förändringar eller efterlevnad av direktiv. Inte heller denna rätt är obegränsad. Åtminstone i teorin är statens våldsanvändning kringgärdad av en rad regler för att skydda medborgarna från militära eller polisiära övergrepp. Även statens användning av văld gentemot andra stater är på samma sätt lagligt begränsad. FN-stadgan förbjuder annan användning än sådan som kan motiveras med självförsvar (artikel 51).

Men frågan om "rätt" har inte endast en legal aspekt. Där finns också en moralisk fråga. Spännvidden går från rätten att alltid försvara/förverkliga vissa värden med hjälp av våld till att inga värden nảgonsin kan försvares/förverkligas till priset av någons död. Spännvidden har närmast förstärkts under senare år. 1970- och 1980talen uppvisar exempel på såväl radikalterrorism som radikalpacifism. Exempel på det förra är de shiamuslimska flickor som i Libanon körde lastbilar fullastade med dynamit rakt in i militärförläggningar, till en säker död för dem själva och för åtskilliga andra. Exempel på det senare är de helt obeväpnade katolska nunnor som ställde sig framför Marcos-regimens pansarbilar i Manila. Frågan om "rätt" at använda våld är en moralisk fråga av stor politisk vikt, eftersom våldet är en viktigt instrument för statens maktutövning. Ett stort antal grupper i världen av idag anser inte att staten har monopol på att avgöra vem som har denna "rätt" och under vilka omständigheter. I stället avgör de frågan på egen hand och för egen del. Det kan ibland resultera i att grupper organiseras för att använda våld även mot staten för att förverkliga till exempel en samhällsförändring eller en ny statsbildning. Det kan också resultera i att grupper använder icke-våldsmetoder mot statens maktutövning. Kanske kan den senare delen av 1900-talet karaktäriseras som den period då statens tolkningsmonopol vad gäller våldets berättigande brutits.

Världens konflikter är på många avgörande punkter annorlunda än vardagskonflikterna. Det är viktigt att minnas dessa skillnader. Det innebär blant annet att de flesta våldsaktioner inte sker spontant och oorganiserat. Snarare tvärtom. Eftersom våldet utförs av organisationer, kräve: de kollektiva beslut, alternativa planer och betydande förberedelser. De är kostsamma och involverar många personer. Beslutsfattandet kommer alltså ske genom en betydligt mycket mer komplex process än vad fallet är då en berusad person griper efter ett verktyg för att ge eftertryck åt sin uppfattning i ett privat gräl.

Det innebär emellertid inte att inte pyskologiska frågor kan spela en stor roll. Gruppdynamik kan leda till låsningar, snarare än till öppningar, den beslutande gruppen kan vara sammansatt av individer med likartade pyskologiska drag, ibland är det enstaka personer som fattar det "yttersta" beslutet. Vissa personlighetsdrag hos några få individer kan därmed fă stor betydelse och genomsyra en hel organisation. Ett 
svårtfångat samspel sker mellan psykologiska och sociologiska förhållanden. Forskningen står ännu bara $\mathrm{i}$ början av sitt studium av detta.

Lất oss nu närmare skärskåda det organiserade, politiska våldet som ytövas i dagens värld. Syftet är därvid att dels ge en bild av hur de konfliktmönster ser ut som uttrar sig i faktiskt konfliktbeteende, dels att resa frågan om dessa konflikter kan lösas på ett mer varaktigt sätt.

\section{Världens konflikter: historiska mönster}

Den mest noggrannat och systematiska undersökningen av väpnade konflikter har utförts av Correlates of War-projektet vid University of Michigan i Ann Arbor, Michigan, USA. Projektet ger detaljer om krig, inbördeskrig och militära konflikter sedan 1816. Ur denna rika datamängd kan en bild erhållas över de viktigaste konfliktmönstren i modern historia (Small and Singer, 1982).

Under perioden 1816-1980 ägde $118 \mathrm{krig}$ rum där de stridande parterna var stater eller statsliknande enheter. Bland dessa finns såväl omfattande mellanstatliga krig som de första och andra världskrigen, som imperiatistiska krig, till exempel de stora kolonialmakternas erövring av Afrika. Listan innehåller ett antal fortfarande pågående och mycket kostsamma krig: Sovjetunionens intervention i Afghanistan, kriget mellan Iran och Irak och konflikten mellan Etiopien och Somalia.

Till detta kommer en lista på inbördeskrig. Forskarna i Michigan räknar med 106 sådana krig sedan 1816. Totalt skulle världen alltså under 165 år ha skådat 224 krig. Vart och ett av dessa har, enligt projektets definition, varit så omfattande våldshandlingar att minst 1000 personer dödats. I de mellanstatliga krigen rör det sig vanligen om dödade i strid, medan alla de civila konsekvenserna inte räknats med. När det gäller inbördeskrig är det svårare att dra en klar linje mellan stridande och civila. Det är inte utan orsak som inbördeskrig på andra språk kallas "civil wars", eller "medborgarkrig", dvs att civila deltar i striderna och drabas av dem på ett kanske mer urskiljningslöst sätt än vad fallet är då organiserade arméer drabbar samman.

Antalet dödade människor i dessa krig är alltså betydligt högre. Alla krig har stora konsekvenser för det civila samhället. Farsoter, ekonomiskt kaos, omflyttningar kräver en stor tribut, samhällsekonomin inriktas på militära ansträngningar, med följd att andra samhällsuppgifter inte kan fullgöras.

Det är instruktivt att närmare skärskåda de data som Michiganprojektet innehåller. En ögonblicksbild ges av att se på de mest förödande krigen, om vi behandlar kategorierna tillsammans. Resultatet framträder i tabell 1 . Atta av de 224 krigen har resulterat $\mathrm{i}$ mer än en miljon dödade människor. Av dessa har sju utspelats sig under den senare delen av hela period, sedan 1914. Det innebär att en person som idag är lite drygt 70 år (till exempel den genomsnittlige skandinaviske pensionären) under sin levnad upplevt det alldeles övervägande flertalet av de mest förödande krigen. Även i en mycket långt historiskt perspektiv tillhör 1900-talet ett av de mest våldsamma århundradena. Närmast kan det jämföras med 1600-talets Europa.

Om detta betyder att det varit mer konflikter under 1900-talet kan diskuteras. Krigen kan snarare varit "moderna" $i$ den meningen att allt vad den moderna civilisationen haft att erbjuda av teknologiska framsteg också kommit att användas för militära ändamål. En så civil uppfinning som flyget har, ju längre 1900-talet framskridit, 
Tabell 1 . De åtta mest förödande krigen, 1816-1980. Krig med minst en miljon dödade i strid. Inbördeskrig med minst en miljon människor dödade.

\begin{tabular}{|c|c|c|c|}
\hline Krig/inbördeskrig & Tid & Plats & Aktörer \\
\hline Andra Världskriget & $1939-1945$ & $\begin{array}{l}\text { Europa, } \\
\text { Asien, } \\
\text { Afrika }\end{array}$ & 29 stater \\
\hline Första Världskriget & $1914-1918$ & $\begin{array}{l}\text { Europa, } \\
\text { Asien, } \\
\text { Afrika }\end{array}$ & 15 stater \\
\hline Koreakriget & $1950-1953$ & Asien & $\begin{array}{l}\text { Nord- och Syd-Korea, USA } \\
(\mathrm{FN}) \text {, Kina }\end{array}$ \\
\hline Kina & $1860-1864$ & Asien & $\begin{array}{l}\text { Kejsarmakten mot Taiping } \\
\text { (inbördeskrig) }\end{array}$ \\
\hline Vietnamkriget & $1965-1975$ & Asien & $\begin{array}{l}\text { Nord- och Syd-Vietnam, } \\
\text { USA }\end{array}$ \\
\hline Kina & $1946-1949$ & Asien & $\begin{array}{l}\text { Nationalister mot kommuni- } \\
\text { ster (inbördeskrig) }\end{array}$ \\
\hline Nigeria & $1967-1970$ & Afrika & $\begin{array}{l}\text { Centralmakten mot Biafra } \\
\text { (inbördeskrig) }\end{array}$ \\
\hline Japan-Kina & $1937-1941$ & Asien & Kina, Japan \\
\hline
\end{tabular}

Anm.: Kriget Japan-Kina räknas efter 1941 som del av andra världskriget

Källa: Small and Singer, 1982.

utvecklats till ett raffinerat stridsmedel riktat mot såväl militära som civila mål. Under 1960- och 1970-talet blev det civila flyget, för vissa grupperingar, ett i sig legitimt militärt mål. Den civila uppfinningen autombilen omvandlades snart till pansarfordon och stridsvagnar med oerhörd offensiv kraft, osv.

1900-talets höga siffror kan också förklaras med att många krig utspelat sig i mycket tättbefolkade områden. Europa, Östasien och flodområden i Afrika tillhör dessa. I sådana fall får krigen givetvis stora följder. Arméerna är större och flera människor drabbas av stridshandlingarna.

Än så länge har vi endast uppehållit oss vid åtta av de mest förödande krigen. Det finns alltså ytterligare 216 krig som kostat minst 1000 människor livet. Därtill kommer att de amerikanska forskarna dragit en gräns vid 1000. Det finns också en rad konflikter som innehåller våld eller hot om våld som inte når upp till detta tal, men ändå kan vara mycket traumatiska för de involverade och för resten av världen. Ett exempel är Kubakrisen 1962, som inte ledde till några stridigheter men som inte desto mindre betraktas som en av de allvarligaste sammenstötningarna mellan kärnvapenmakterna USA och Sovjetunionen. Forskarna talar därför om "allvarliga dispyter", dvs. militära konfrontationer, där hot om våld uttryckligen förekommer eller där våld används i begränsad omfattning. Correlates of War-projektet inkluderar en lista på 960 sådana konflikter för perioden 1816-1976 (Gochman and Maoz, 1984). Till detta kunde vi också föra militära konfrontationer inom stater, dvs repression och förtryck som inte resulterat $\mathrm{i}$ inbördeskrig eller mellanstatliga krig men ändå är högst påtaglika för alla. 
Sådana situationer har inte räknats i projektet. De uppgifter som tas fram av organisationer som arbetar för mänskliga rättigheter utgör ett relevant kompletterande material.

Dessa siffror är mycket höga. De säger klart att rustningar sällan är till för parader eller övningar. De flesta stater och regeringar använder, vid ett eller annat tillfälle, sina vapen aktivt. Sedan det första världskriget är det endast två stater som inte varit inblandade i krig, inbördeskrig eller militära kupper: Schweiz och Sverige (Wallensteen, 1973: 109).

\section{Världens konflikter: moderna mönster}

De data vi hittills presenterat täcker en 165 år lång period. Har då inte världen förändrats i något grundläggande avseende? Skiljer sig inte tiden efter 1945 från den före? Det finns åtminstone två skillnader som borde påverka konfliktmönstren. De tre fascistiska stormakternas nederlag i det andra världskriget innebar att en regimtyp baserad på våld och chauvinism försvann. Tillkomsten och användningen av kärnvapen innebar att vapen av en sådan oerhörd förstörelseförmåga tillfördes att krig som medel måste betraktas i ett nytt ljus. Dessa två omvälväningar återspeglar sig inte så tydligt i konfliktstatistisken som man kanske skulle förvänta sig. Tabell 2 ger relevanta data.

Tabell 2. Krig, inbördeskrig och militära konfrontationer sedan 1816.

\begin{tabular}{lccc}
\hline & $\begin{array}{c}\text { Totalt antal } \\
\text { efter 1945 }\end{array}$ & $\begin{array}{c}\text { Antal per år } \\
\text { efter 1945 }\end{array}$ & $\begin{array}{c}\text { Antal per år } \\
\text { före 1945 }\end{array}$ \\
\hline Krig & 26 & 0.7 & 0.7 \\
Inbördeskrig & 41 & 1.2 & 0.5 \\
Konfrontationer & 393 & 12.7 & 4.4 \\
\hline
\end{tabular}

Källa: Small and Singer, 1982 (krig, inbördeskrig); Gochman and Maoz, 1984 (konfrontationer).

I tabell 2 jämförs konflikter per tidsenhet för perioderna före och efter 1945. Den visar att varken antalet krig eller inbördeskrig minskat under denna tid. I själva verket har inbördeskrigen fördubblats medan de militära konfrontationerna nästan är tre gånger så många som tidigare. Denna information stämmer väl med vad som kan utläsas i Tabell 1: fyra av de mest förödande krigen finns i perioden efter 1945: inbördeskrigen i Kina och Nigeria, samt Korea- och Vietnamkrigen. Tabell 2 ger inte något stöd för tanken att konflikterna skulle ha blivit färre efter det andra världskriget. Vissa typer av konflikter har försvunnit. Vi vet inte heller hur läget varit med en annan utgăng av det andra världskriget. Men varken eliminerandet av fascismen eller användningen av kärnvapen tycks ha gjort vår tid mindre konfliktbemängd än andra tider.

De mest markanta förändringarna är i stället ökningen av inbördeskrig och av militära konfrontationer. Många skulle kanske relatera detta till att de blivit betydligt fler aktörer i världen. Eftersom antalet stater ökat så är det rimligt anta att också mängden konflikter borde öka. Rent statistiskt kan vi därför finna en minskning av krig och 
inbördskrig per stat. Eftersom antalet stater var färre förr så skulle alltså vår tid rent statistiskt se mindre krigisk ut, trots at det är fler krig per tidsenhet. Man kan fråga om detta är en rimlig operation. Under detta ligger en föreställing om att ju färre enheter desto färre kan slåss och följaktligen blir det färre krig. Världens fred skulle alltså kunna säkerställas genom en världsstat. Men man kunde också hävda att ju mer maktkoncentration desto mer begärlig blir makten och desto intensivare blir kampen om makten. Vi talar med andra ord om bestämda orsaksamband och förklaringar. Det är inte vår uppgift $\mathrm{i}$ just detta sammanhang och vi kan därför nöja oss med att konstatera att de olika våldsformerna idag är lika eller mer vanliga än de varit tidigare $\mathrm{i}$ historien. Vad detta beror på är en betydligt mer omfattande diskussion än vad vi just nu går in på.

Fyra av de mest omfattande krigen har utspelats efter 1945. Det är viktigt att påpe$\mathrm{ka}$ att kärnvapenmakter deltog aktivt men på olika sätt i samtliga fyra. I två av konflikterna var en kärnvapenmakt engagerad med stora omfattande egna styrkor (Koreaoch Vietnamkrigen, USA stödde $\mathrm{i}$ båda fallen sydsidan). I tre av konflikterna fanns kärnvapenmakter som vapenleverantörer på båda sidor (Sovjetunionen som leverantör till nordsidan i Korea- och Vietnamkrigen, och tillsammans med Storbritannien till centralregeringen i Nigeria - Biafrakriget, där Frankrike stödde Biafra-sidan). I samtliga fyra konflikter fanns minst en kärnvapenmakt engagerad och en annan stormakt på den andra sidan (i Kina stödde USA aktivt nationalisterna, Sovjetunionen kommunisterna). Inte i något av dessa fall kom kärnvapen till användning. Meń vetskapen om att kärnvapen skulle kunna komma att dras in hindrade uppenbarligen inte konflikterna från att bryta ut $\mathrm{i}$ krig. Inte eller hindrade rädslan för upptrappning stormakter att engagera sig på motsatta sidor. Det potentiella hotet från kärnvapen tycks inte heller ha förkortat stridshandlingarna. Inte desto mindre finns information om att till exempel USA övervägt användning av kärnvapen i såväl Korea- som Vietnamkrigen. Sådana informationer har också publicerats för andra konflikter, till exempel i samband med Viet Minhs inringning av den franska garnisonen i Dien Bien Phu 1954.2

Kärnvapen har alltså inte avhållit stormakter från att engagera sig i lokala konflikter världen över. Därmed kan vi inte säga att kärnvapen allmänt minskt konfliktmängden i världen. I stället kan vi fråga oss om inte den markanta ökningen av militära konfrontationer under perioden efter 1945 bland annat återspeglar just kärnvapens förekomst. Världen har efter 1945 bevittnat ett ovanligt stort antal konfrontationer mellan stormakterna (Wallensteen, 1981: 74). Vetskapen om kärnvapen skulle alltså kunna påverka just stormakternas inbördes relationer, men i övrigt ha en begränsad effekt på världens konfliktmönster. Stormakternas inbördes konflikter utspelas idag, kanske i högre grad än tidigare, med kriser, dramatiska utspel, överraskande, men lokalt begränsade aktioner, etc.

I ett historiskt perspektiv kan vi notera att perioden efter 1945 sett många fler stormaktskonfrontationer som inte resulterat i krig än tidigare perioder. Konfrontationsagerande är därmed något karaktäristiskt för vår tid och det har paralleller endast om man går till de 15 åren närmast före det första världskriget. De historiska lärdomarna visar samtidigt att en viss mängd sådana konfrontationer kan stormakterna klar utan krig, men vanligen har det kommit en kris som "missbedömts". (Wallensteen 1981; Small and Singer, 1982). Faran kan till exempel ligga i att ledningen för en 
stormakt tror att den kan tvinga motsida till eftergifter med hot om krig, eftersom det "gick" i en tidigare krig, samtidigt som den andra ledningen lärt sig att inte vika för just ett sådant hot. Om båda antar att det gäller att vara "tuff" därför att den andra sidan egentligen "bluffar" så kan en kris snabbt trappas upp till ett storkrig. Sedan 1945 har såväl USA som Sovjetunionen erfarenheter som kan leda till sådana slutsatser. I amerikansk debatt framställs ofta Kubakrisen som ett exampel på att "tuffhet" lönar sig. Sovjet uppnådde 1969 liknande kortsiktiga framgångar i en konfrontation med Kina (Robinson 1981: 265-313). En närmare analys av båda dessa situationer visar att utgången bestämdes av en rad faktorer, där "tuffheten" till exempel kompletterades med "mjukhet" så att den andra sidan kunde söka en hedersam reträtt.

Riskerna för ett kärnvapenkrig knyts med andra ord till hur kriser hanteras mellan stormakterna. Därmed har vår tid kanske fler paralleler med 1914 än 1941. Men samtidigt är kanske ledare i såväl USA som Sovjet mer formade av de överraskande anfallen 1941 än den stegvisa upptrappningen 1914. Det skulle bland annat innebära att de mer är rädda för att "förlora" $i$ en konflikts inledande krigiska skede än för upptrappningsrisken som sådan.

\section{Vad handlar konflikterna om?}

Omedelbart efter det andra världskriget handlade en stor del av konfliktmaterien om just detta krigs utgång. Krigets segrarmakter hade de avgörande inflytandet över hur territorier skulle hanteras, vilka regimer som skulle accepteras, militära dispositioner som skulle vidtas, osv. Deras oförmåga att vidmakthålla krigstidens allians medförde att en rad av dessa frågor blev härdar för konflikt i stället för grund för samarbete. Till detta kom kolonialmakternas försök att återupprätta sina forna imperierna sedan dessa raserats av Japan och av lokala befrielserörelser. Fram till början av 1960-talet dominerades stormaktskonflikterna av frågro som hörde samman med Tysklands och Japans tidigare inflytande. Avkoloniseringen under 1960- och 1970-talen förändrade stormakternas konfliktmönster.

Det innebär att 1980-talets konflikter till övervägande del utspelas i den tredje världen. USA och Sovjet tar en aktiv del i många av dessa. Frankrike spelar en militär roll i vissa konflikter i Afrika, Karibien och Oceanien. Storbritannien har efter hand intagit en mer tillbakadragen roll, men kriget 1982 med Argentina över Falklands/ Malvinasöarna var en påminnelse också om dess kvarvarande koloniala besittningar. ${ }^{3}$

En diskussion har utbrutit om dagens många konflikter i tredje världen är "interna" eller "externa". Eftersom vapenproduktion och vapenhandel domineras av några får stormakter blir deras inflytande betydande så snart en väpnad konflikt blir militärt omfattande. Stormakter och andra externa intressenter får möjlighet att påverka såväl krigets utformning som konfliktens lösning. Det "externa" inflytandet är stort och påtagligt.

De oförenligheter konflikterna utspelas kring kan emellertid vara nog så "interna". Om vi utgår från de faktiska väpnade konflikterna och ser på de ledande parterna framträder tre typer av konflikter:

1) Konfikter mellan stater, dvs. de "klassiska" mellanstatliga konflikter som handlar om gränser, lokalt eller regionalt inflytande och som ibland sammanfaller med 
historiska motsättningar mellan folkgrupper. Dessa konflikter är dem som delvis återfinns i kategorierna mellanstatliga krig och militiära konfrontationer i tabell 1 och 2.

2) Konflikter om regeringsmakten i en stat, dvs de "klassiska" inbördeskrigen om kontrollen över statsmakten. I detta fall är det ofta statsmaktens unika drag, som vi beskrivit i första avsnitt, som gör den åtråvärd. Den som kontroller staten kan förverkliga en rad personliga eller kollektiva önskemål. Följaktligen blir statens ensamrätt till bland annat tvångsmakt en konfliktanlednig i sig. Dessa konflikter återfinns $\mathrm{i}$ huvudsak $\mathrm{i}$ gruppen inbördeskrig $\mathrm{i}$ tabell 1 och 2 .

3) Konflikter om statbildningen som sådan, dvs. konflikter om vilka stater som ska finnas. Denna kategori är inte klart urskiljbar i statistiken ovan. Ibland beskrivs dessa konfliker som inbördeskrig, ibland som mellanstatliga krig. De handlar om att företrädare för en viss etnisk (nationell, språklig, religiös, kulturell) grupp hävdar att gruppens säkerhet endast kan tillfredsställas inom ramen för en egen statsbildning. De kan innehålla krav som sträcker sig från autonomi inom existerande stater via skapande av en helt egen stat till önskemål om anknytning till annan stat.

Som tabell 1 ger prov på, är krig av den första typen särskilt destruktiva, samtidigt som tabell 2 visar att de inte är så många som man kanske kunde förvänta sig. Två väpnade organisationer som står mot varandra kommer delvis att avskräcka varandra och därmed kanske länka in konflikter på andra banor. Om ett krig utbryter kommer det emellertid att bli oerhört destruktivt eftersom krigsmaskinerierna finns färdiga, tränade och finansierade på båda sidor. Dagens mest förödande krig är kriget mellan Iran och Irak.

Även inbördeskrig kan vara mycket destruktiva, det framgår av tabell 1. Men samtidigt finns det betydligt fler krig av denna typ, enligt tabell 2. Många av dem är begränsade. I själva verket finns här en betydande variation, om vi också inkluderar krig som drabbar färre än 1000 döda. En rad uppror och kupper kan vara relativt oblodiga, vare sig de lyckas eller ej. Ser vi till alla former av väpnat politiskt våld som förekommer hamnar förmodligen en mycket stort del i denna kategori.

Den tredje kategorin avser en typ av konflikter som har ökat markant under senare år, inte enbart i den tredje världen. En rad etniska grupper med viss territoriell koncentration har krävt ökad självstyre och hävdar att de utsatts för övergrepp från andra grupperingar. Ofta beskriver de sin kamp som en fortsättning av en nationell antikolonial befrielsekamp, där orättvisan i grunden skapats av de gränser som kolonialmakterna dragit upp och som accepterats även efter avkoloniseringen.

Alla typer av konflikter kan leda till mellanstatlig inblandning. I de första fallet kan andra stater dras med av alliansförhållanden eller av farhågor om vad utgången annars kan bli. I det andra fallet utspelas konflikterna ofta längs en höger-vänster axel som intresserar stormakterna. I det tredje fallet kan finnas etnisk frändskap som gör grannländer till medaktörer eller aktiva interventerare. Världens konflikter består idag av en rad konfliktkomplex där konflikter flätats in i varandra. I takt med att konfliktmönstren blir mer komplexa ändras till exempel stormakternas uppträdande. Några exempel kan vara belysande. 
Ett exempel är Palastinaproblematiken där samtliga grannländer dragits in, och där aktioner utspelas långt från själva konfliktområdet, inom Medel- och Rödahavsområdena. USA och Sovjet har skaffat sig allierade på ömse sider om konfliktlinjerna. Vid flera tillfällen har supermakterna stått öga mot öga i konflikter som utvecklats ur just dessa förhållanden, till exempel under Oktoberkriget 1973.

Ett annat exempel är södra Afrika problematiken, där Sydafrikas apartheidsystem och motståndet mot detta omfattar samtliga grannländer. Sydafrika har i sin tur finaniserat rörelser mot regimerna i dess länder och riktat direkta attacker mot samtliga kringliggande stater. Även relativt avlägsna stater i Indiska oceanen har drabbats av denna konflikt. Sydafrikaproblematiken är en av de få konflikter där USA och Sovjet uppträtt gemensamt till exempel i FNs säkerhetsråd. Vapenembargot från 1977 förutsatte ett nära samförstånd mellan Carteradministrationen i USA och Brezjevregimen i Sovjet. Under 1980-talet har emellertid USA ändrat hållning och aktivt stött till exempel gerillan i Angola som strider mot landets regim, som i sin tur förlitar sig på militärt stöd från Kuba och Sovjet.

Ett tredje exempel på ett konfliktkomplex är Afrikas Horn, där konflikten mellan Etiopien och Somalia tidvis kopplats ihop med andra regionala konflikter i Etiopien och med maktstrider i Somalia. I denna konflikt svängde Sovjetunionen från att stödja Somalia till att militärt intervenera på Etiopiens sida, samtidigt som USA engagerat sig för Somalia.

Et fjärde exempel är Cypernproblematiken, där Turkiet nu ockuperar närmare 40 procent av en tidigare självständig stats territorium. Detta har resulterat i en allvarlig konflikt mellan Grekland och Turkiet, som båda är medlemmar av NATO. För att undvika en NATO-inblandning har den cypriotiska regeringen inkallat FN-styrkor.

Att konflikter utvecklas till konfliktkomplex innebär att de blir allt mer komplicerade. Andra aktörer än de "ursprungliga" gör sina kalkyler för att avgöra vad som gynner/missgynnar dem. Inte minst kommer därvid strategiska och militära bedömningar in i bilden. Resultatet blir lätt att konflikter ömsesidigt förstärker varandra. Att resonera om konfliktlösning blir därmed mycket komplicerad, eftersom parter gått med i konflikten därför att de räknat med att gynnas av en viss utveckling. Konfliktlösningen kan komma $i$ vägen för dessa intressen.

\section{Om konfliktlösningens möjlighed}

Att lösa en konflikt innebär att finna en samlevnadsform mellan de stridande parterna där de kan acceptera varandras rätt till existens och finna former för att hantera meningsskiljaktligheter. Konfliktlösning är därmed inte det samma som seger/nederlag för den ena parten. Vanligen syftar konfliktbeteende till att eliminera motparten eller tvinga motparten att acceptera en viss lösning. I detta fall resulterar konflikten i den ena sidans dominans över den andra. Inte heller innebär konfliktlösning att all konfliktbeteende upphör. Konfliktlösning innebär att konfliktbeteende kanaliseras in i former som parterna kan acceptera.

Ett viktigt inslag i konfliktlösning är att såväl de militära som de "politiska" delarna av konflikten behandlas. Det innebär att strider måste upphöra, militära förband skiljas åt och att former för rustningskontroll eller avrustning måste utarbetas. Vapnen innehåller i sig tillräcklig stoff för att vidmakthålla rädsla och oro mellan parter- 
na. En varaktig konfliktlösning är sällan möjlig utan att den kopplas just till rustningskontroll.

Det centrala är emellertid de "politiska" delarna av konflikten, dvs. de frågor som utgör konfliktens kärna. Vad det är som är centralt kan parterna vara oeniga om. En lösning behöver därmed ta fasta på vad parterna själva anser vara viktigt. Det är vanligen syftet med krav på förhandlingar från de utanförstående. Endast i förhandlingssituationen kan en part få klart för sig vad motparten egentligen tycker är viktigt, och vad som är av publicitetskaraktär. Men marken kan beredas för förhandlingar, inte endast genom förhandskontakter utan också genom till exempel ensidiga åtgärder som ökar förtroendet mellan parterna och inger en känsla av seriösa avsikter.

De tre grundtyperna av konflikter har olika modeller för lösning. I de konfliktkomplex som föreligger kan man använda sig av olika lösningsstrategier, men att utgå från grundkonflikten är förmodligen det mest rimliga. Låt oss kort peka på några möjliga lösningar.

För lösning av de mellanstalliga krigen finns såväl internationella organisationer som internationella lagar och historiska förebilder. FN har tillkommit som en organisation för lösning av just denna typ av konflikter. FNs begränsningar är därmed ett uttryck för stormakternas och andra staters ointresse av att vidareutveckia internationella institutioner för konfliktlösning. I jämförelse med andra typer av konflikter har relationerna mellan stater vissa fördelar. Det finns ofta diplomatiska relationer, direkt eller indirekt mellan parterna. Sällan ifrågasätts den andra statens rätt att existera. Det finns därmed visst utrymme för förhandling. Modeller finns till exempel för hantering av gränsfrågor. Även frågor om lokalt och regionalt inflytande är delbara, eftersom inflytande är en ganska vag term och kan avse olika saker. Lösning av mellanstatliga konflikter handlar ofta om att ge utrymme för medling eller andra tredjepartsingripanden.

I fallet Iran och Irak begränsas detta utrymme kraftigt av att konflikten inte endast handlar om gränsfrågor utan också kommit att kopplas till regimsammansättning. Sådana frågor är sällan förhandlingsbara, eftersom de innebär att en stat söker diktera vem som ska styra $i$ den andra.

Lösning av inbördeskonflikter kan vara både svårare och lättare att nå, det ses också i det faktum att dessa konflikter är mycket varierande i omfattning. Eftersom de handlar om kontroll över den centrala statsapparaten rör de frågor som särskilt berör statskunskapen. De västerländska demokratierna är ett sätt att lösa maktstridigheter, som hittills fungerat och minskat våldsamheten i dessa. Dessa system har vuxit fram under en längre och utformats av olika interna konflikter. En intressant fråga är hur det varit möjligt att nå enighet om spelreglerna på det sätt som skett och vilka villkor som behöver uppfyllas för att detta ska kunna upprepas under andra omständigheter, till exempel i Sydamerika? Viktiga inslag är bland annat den öppna valproceduren, där alla parter kan vara med på lika villkor såväl i kampanj som i rösträkning, och möjligheten av att, $i$ händelse av valnederlag, få en ny chans inom 3-4 år. Inbördeskrigen är antagligen vanligare och intensivare $i$ länder utan sådana fungerande lösningar.

Lösning av statsformationskonfikter erbjuder särskilda problem eftersom de för in ett territoriellt moment inom en en viss statsbildning eller till och med kräver att statens gränser ritas om. Lösningarna varierar från regional autonomi via federativa statsbildningar till faktiskt delning av staten. Komplikationerna är många eftersom få 
områden är helt etniskt homogena. Det innebär att etnisk konflikt kan uppkomma hur man än drar up gränserna. Problemet kan därmed inte alltid nå sin lösning endast med en territoriell konstruktion.

Karaktäristiskt för såväl inbördes- som statsformationskonflikterna är att staten/ regeringen ofta har mycket svårt att acceptera en väpnade upprorsrörelse som en legitim samtalspartner. Eftersom staten har monopolet på våldsanvändningen är sådana väpnade grupper närmast "kriminella". Det innebär att när konflikten går från en icke-väpnad till en väpnad kamp viktiga trösklar passeras: det mänskliga lidande ökas, de organisatoriska kraven förstärks och förhandlingsmöjligheterna reduceras. Konflikter kan med andra ord förmodligen lösas snabbast och effektivast så länge de befinner sig i ett icke-väpnat stadium.

\section{Noter}

1. Om skillnaderna mellan statliga och icke-statliga aktörer, se Wallensteen, 1981: 57-58; 1985.

2. Ellsberg, 1981, innehåller en lista baserad bland annat på memoarlitteratur. Blechman and Kaplan, 1978: Part I, ger en mer systematisk lista på sådana situationer.

3. Denna och följande information om väpnade konflikter baseras på ett projekt som pågår vid institutionen för freds- och konfliktforskning vid Uppsala universitet.

\section{Litteratur}

Blechman, B. and Kaplan, S. (eds.) (1978). Force without War, Washington, D.C.: Brookings.

Ellsberg, D. (1981). "Introduction", i Thompson, E. P. (ed.), Protest and Survive, New York: Mouthly Review Press.

Gochman, C. and Maoz, Z. (1984). "Militarized Interstate Disputes, 1816-1976", foumal of Conflict Research, Vol. 28: 4.

Robinson, T.W. (1981). "The Sino-Soviet Border Conflict", s. 265-313 i Kaplan, S. S. (ed.), Diplomacy of Power, Washington, D.C.: Brookings.

Small, M. and Singer, J.D. (1982). Resort to Arms. International and Civil Wars, 1816-1980, Beverly Hills: Sage.

Wallensteen, P. (1973). Structure and War. On International Relations, 1920-1968, Stockholm: Rabén \& Sjögren.

Wallensteen, P. (1981). "Incompatibility, Confrontation and War: Four Models and Three Historical Systems, 1816-1976", fournal of Peace Research, Vol. 18: 1.

Wallensteen, P. (1985). "Incompatibility, Militarization and Conflict Resolution", s. 219-234 i Wallensteen, P. et al. (eds.), Global Militarization, Boulder, Co.: Westview Press. 
områden är helt etniskt homogena. Det innebär att etnisk konflikt kan uppkomma hur man än drar up gränserna. Problemet kan därmed inte alltid nå sin lösning endast med en territoriell konstruktion.

Karaktäristiskt för såväl inbördes- som statsformationskonflikterna är att staten/ regeringen ofta har mycket svårt att acceptera en väpnade upprorsrörelse som en legitim samtalspartner. Eftersom staten har monopolet på våldsanvändningen är sådana väpnade grupper närmast "kriminella". Det innebär att när konflikten går från en icke-väpnad till en väpnad kamp viktiga trösklar passeras: det mänskliga lidande ökas, de organisatoriska kraven förstärks och förhandlingsmöjligheterna reduceras. Konflikter kan med andra ord förmodligen lösas snabbast och effektivast så länge de befinner sig i ett icke-väpnat stadium.

\section{Noter}

1. Om skillnaderna mellan statliga och icke-statliga aktörer, se Wallensteen, 1981: 57-58; 1985.

2. Ellsberg, 1981, innehåller en lista baserad bland annat på memoarlitteratur. Blechman and Kaplan, 1978: Part I, ger en mer systematisk lista på sådana situationer.

3. Denna och följande information om väpnade konflikter baseras på ett projekt som pågår vid institutionen för freds- och konfliktforskning vid Uppsala universitet.

\section{Litteratur}

Blechman, B. and Kaplan, S. (eds.) (1978). Force without War, Washington, D.C.: Brookings.

Ellsberg, D. (1981). "Introduction", i Thompson, E. P. (ed.), Protest and Survive, New York: Mouthly Review Press.

Gochman, C. and Maoz, Z. (1984). "Militarized Interstate Disputes, 1816-1976", foumal of Conflict Research, Vol. 28: 4.

Robinson, T.W. (1981). "The Sino-Soviet Border Conflict", s. 265-313 i Kaplan, S. S. (ed.), Diplomacy of Power, Washington, D.C.: Brookings.

Small, M. and Singer, J.D. (1982). Resort to Arms. International and Civil Wars, 1816-1980, Beverly Hills: Sage.

Wallensteen, P. (1973). Structure and War. On International Relations, 1920-1968, Stockholm: Rabén \& Sjögren.

Wallensteen, P. (1981). "Incompatibility, Confrontation and War: Four Models and Three Historical Systems, 1816-1976", fournal of Peace Research, Vol. 18: 1.

Wallensteen, P. (1985). "Incompatibility, Militarization and Conflict Resolution", s. 219-234 i Wallensteen, P. et al. (eds.), Global Militarization, Boulder, Co.: Westview Press. 